\title{
Subulura lacertilia sp.n. (Nematoda, Subuluridae) parasitizing the Brazilian lizard Tropidurus nanuzae Rodrigues (Lacertilia, Tropiduridae)
}

\author{
J. Julio Vicente ${ }^{1,4}$ \\ Monique Van Sluys 2,4 \\ Angelica F. Fontes 2,5 \\ Mara Cintia Kiefer ${ }^{3,6}$
}

\begin{abstract}
This report deals with the identification of samples of nematodes recovered from Tropidurus namuzae Rodrigues, 1981, with the description of a new species, and is a part of a major study on helminth parasites of reptiles in Brazil, taking into account previous data on this subject. The main approach is that referring to the first occurrence of subulurid nematodes in a reptilian host, since they have been assigned previously to birds and mammals.

KEY WORDS. Nematode, Subulura, Tropidurus, lizard, Brazil
\end{abstract}

The Subuluridae nematodes are found in various orders of birds (Tinamiformes, Passeriformes, Strigiformes, Caprimulgiformes, Piciformes and Gruiformes) (VICENTE et al. 1995) and in mammals as Primata, Marsupialia, Rodentia (VICENTE et al. 1997). The present investigation reports to the proposal of a new species of parasite of Tropidurus nanuzae Rodrigues, 1981. Considering this fact, results presented herein, refer to the first occurrence of a nematode of the genus Subulura Molin, 1860 in a reptilian host and add new data to those referred by VICENTE et al. (1993).

\section{MATERIALS AND METHODS}

A total of 1215 samples of nematodes recovered from 75 lizards, Tropidurus nanuzae between September/1996 and May/1997 during scientific expeditions to Serra do Cipó $\left(19^{\circ} 20^{\prime}\right.$ 'S $\left.43^{\circ} 44^{\prime} \mathrm{W}\right)$, State of Minas Gerais were studied. The worms were preserved in vials with alcohol $70^{\circ} \mathrm{GL}$. Specimens were stained with carmine, dehydrated in ethanol $\left(80-100^{\circ} \mathrm{GL}\right)$, cleared in phenol and returned to the vials as wet material and a few were mounted in balsam as whole mounts and deposited in

1) Departamento de Helmintologia, Instituto Oswaldo Cruz. Avenida Brasil 4365, 21045-900 Rio de Janeiro, Rio de Janeiro, Brasil.

2) Setor de Ecologia, DBAV, IBRAG, Universidade do Estado do Rio de Janeiro. Rua São Francisco Xavier 524, 20550-900 Rio de Janeiro, Rio de Janeiro, Brasil.

3) Departamento de Zoologia, Intituto de Biologia, Universidade Estadual de Campinas. Caixa Postal 6109, 13083-970 Campinas, São Paulo, Brasil.

4) Bolsa de Produtividade em Pesquisa do CNPq.

5) Bolsa de Iniciação Científica do PIBIC/UERJ.

6) Bolsa de Doutorado/CNPq. 
the Helminthological Collection of the Oswaldo Cruz Institute (CHIOC). Preparation of "en face" mounts was in accordance to the method of ANDERSON (1958). Illustrations were performed with a drawing tube. Measurements are in millimeters. Classification of the nematodes regarding generic diagnoses follows CHABAUD (1978) and the confirmation of the taxonomic status of the host was based on RODRIGUES (1981).

\section{Subulura lacertilia sp.n.}

Figs 1-6

\section{Description}

Morphometrics: based on ten adult specimens, five males and five females; Subuluroidea, Subuluridae, Subulurinae). Males (Figs 1, 3, 4): body 2.31-4.93 (3.62) $\mathrm{mm}$ long, $0.18-0.25(0.21)$ wide. Mouth with three lips, with six papillae. Oral opening with chordal lobes helix like. Pharynx 0.018-0.032 (0.025) long; Esophagus 0.84-0.92 (0.88) long. Bulb 0.17-0.19 (0.18) long by 0.17-0.21 (0.19) wide. Nerve ring and excretory pore at the same level $0.20-0.245(0.22)$ from the anterior extremity. Spicules equal in size and shape $0.63-0.75(0.69)$ long. Gubernaculum 0.11-0.14 (0.12) long. Cloacal aperture 0.12-0.18 (0.15) from posterior extremity. Eleven pairs of caudal papillae; four pre, two ad and five post-cloacal. Pre-cloacal sucker 0.10-0.13 (0.11) long. Spike of the tail 0.025-0.043 (0.034) long. Females (Figs 2, 5, 6): body 4.45-6.23 (5.29) mm long, 0.20-0.33 (0.26) wide. Pharynx 021-0.032 (0.026) long; 0.025-0.032 (0.028) wide. Esophagus 1.03-1.09 (1.06) long. Nerve ring and excretory pore $0.28-0.35(0.31) ; 0.37-0.46(0.41)$ from anterior extremity respectively. Vulva 2.38-3.26 (2.82) from anterior extremity. Ovijector 0.30-0.36 (0.33) long. Eggs 0.072-0.082 (0.077) long; 0.050-0.064 $(0.054)$ wide. Anus $0.28-0.39(0.33)$ from posterior extremity. Rectum $0.12-0.14$ (0.13) long.

\section{Taxonomic summary}

Type host: Tropidurus nanuzae.

Site of infection: large and small intestine.

Specimens studied: CHIOC no. 34196 a (holotype male), 34196 (alotype), paratypes: 34196 b,c and 34197 b,d,f (males), 34197 a,c,e,g (females) (whole mounts) and 33853-33856 (wet material).

Prevalence of worms was of $73.3 \%$, with a minimum number of 1 and a maximum of 112 (22.2). Standard deviation $=28.1$.

\section{Remarks}

Species of the genus Subulura Molin, 1860, have been referred parasitizing birds and mammals. This is the first report on a reptilian host harbouring subuluroid nematodes. The new species proposed herein, can be compared to $S$. alfenensis Pinto, 1968, S. brumpti (Lopez Neyra, 1922), S. differens (Sonsino, 1890), S. forcipata (Rud., 1819), S. olimpioi, Barreto, 1919, S. rudolphii Santos, 1970 and S. strongylina (Rud., 1819) that possess equal spicules. Subulura lacertilia sp.n. most 

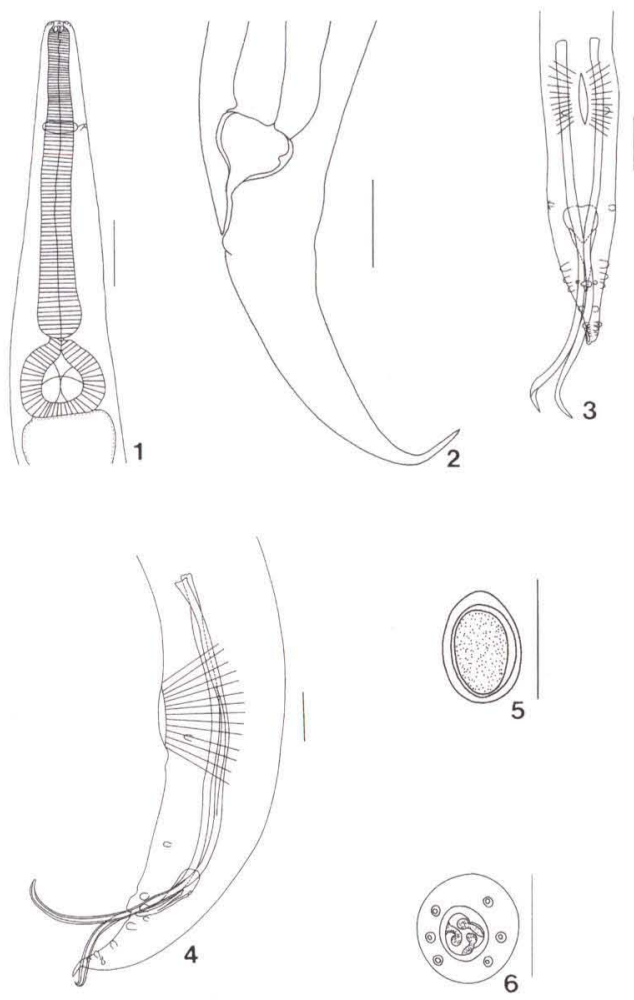

Figs 1-6. Subulura lacertilia sp.n. (1) Anterior portion, lateral view (34197 e); (2) posterior portion of female, lateral view (34197 d); (3) posterior portion of male, ventral view (34196 b); (4) posterior portion of male, lateral view (34196 a); (5) egg (34196 e); (6) oral aperture "en face" view. Bars $=0.1 \mathrm{~mm}$.

resembles $S$. alfenensis and main differences are those related to the small size of males and females, greater length of spicules, size of eggs and the presence of an oustanding esophageal pre-bulbar constriction. The occurrence of subuluroid nematodes in lizards is not to be considered an accidental infection taking into account the high prevalence. According to ANDERSON (1992) current evidence suggests that species of this genus are not highly specific in their use of intermediate hosts (insects). Eggs hatch in the gut of the insect (usually orthopterans, dermapterans or coleopterans) and larvae penetrate the gut wall and attain the body cavity. Lizards of the species $T$. nanuzae eat predominantely ants, isopterans and coleopterans as observed in stomach contents.

ACKNOWLEDGEMENTS. To Dr. R. Magalhães Pinto, Department of Helminthology/IOC, for providing the "en face" mountings, suggestions and critical review of the text. This study was partially supported by a research grant from CNPq (400339/97-8) to MVS. Vinicius B. Assis for helping in the field work. 


\section{REFERENCES}

Anderson, R.C. 1958. Méthode pour l'examen des nématodes en vue apicale. Ann. Par. Hum. Comp. 33: 1712-172.

1992. Nematode Parasites of Vertebrates. Their Development and Transmission. Commonwealth Agricultural Bureaux International, Wallingford, UK, 578p.

Chabaud, A.G. 1978 Keys to genera of superfamilies Cosmocercoidea, Seuratoidea, Heterakoidea and Subuluroidea, p. 1-71. In: R.C. Anderson; A.G. Chabaud \& S. Willmott (Eds). CIH Keys to the nematode parasites of vertebrates 6. Wallingford, Commonwelth Agric. Bureaux Internat, 71p. Rodrigues, M.T. 1981. Uma nova especie de Tropidurus do Brasil (Sauria, Iguanidae). Pap. Avulsos Zool., São Paulo, 34 (13): 145-149.

Vicente, J.J.; H.O. Rodrigues; D.C. Gomes \& R.M. Pinto. 1993. Nematoides do Brasil. Parte III: Nematoides de répteis. Revta bras. Zool. 10 (1): 19-168. 1-273.

1997. Nematóides do Brasil. Parte V. Nematoides de mamíferos. Revta bras. Zool. 14 (Supl. $1): 1-452$

Recebido em 07.XII.1999; aceito em 13.XII.2000. 